\title{
DIVERSIFIKASI PRODUK OLAHAN MANGROVE BISA MENINGKATKAN KESEJAHTERAAN MASYARAKAT PESISIR INDRAMAYU
}

\author{
Sugianto \\ Universitas Wiralodra, Jl. Ir. H. Djuanda KM 3 Indramayu \\ Email: sugianto@unwir.ac.id
}

Citasi: Sugianto. (2019). Diversifikasi Produk Olahan Mangrove Bisa Meningkatkan Kesejahteraan Masyarakat Pesisir Indramayu. Mangifera Edu volume 3 (2): 133139.

\begin{abstract}
ABSTRAK
Potensi pesisir pantai di Indramayu yang banyak ditumbuhi pohon mangrove itu, merupakan aset berharga yang bisa dimanfaatkan untuk meningkatkan kesejahteraan masyarakat. Namun sayangnya kondisi pantai banyak yang rusak akibat terjangan abrasi, hal itu disebabkan hampir 18 ribu hektare hutan pantai di Indramayu kondisinya kritis. Salah satu penyebab utama kerusakan hutan mangrove di Indramayu karena kurang kesadarannya masyarakat tentang manfaat olahan dari mangrove sehingga bernilai ekonomi. Masyarakat berpendapat bahwa menjadikan hutan bakau sebagai area pertambakan lebih menguntungkan dari segi ekonomi ketimbang memanfaatkan mangrove menjadi olahan makanan, minuman atau menjadi bahan baku kosmetik. Oleh karena itu secara umum tujuan dalam penelitian ini yakni (1) merubah paradigma masyarakat pesisir kabupaten Indramayu bahwa tumbuhan mangrove dapat diversifikasi menjadi olahan makanan, minuman dan obat-obat yang bernilai ekonomi tinggi; (2) meningkatkan kesejahteraan ekonomi masyarakat pesisir Indramayu. Metode yang digunakan dalam penelitian adalah metode survey, yaitu metode yang dilakukan untuk mengadakan pemeriksaan yang berlangsung di lapangan atau lokasi penelitian. Data yang digunakan berupa data sekunder dan primer yang dapat diperoleh di lapangan dan studi literatur. Data yang diperoleh dianalisis menggunakan analisis deskriptif kualitatif. Mekanisme kegiatan penelitian ini bekerja sama dengan (1) dinas kelautan dan perikanan kabupaten Indramayu; (2) Persaudaran Perempuan Nelayan Indonesia (PPNI) kabupaten Indramayu; (3) Kelompok posdaya LPPM Universitas Wiralodra yang tersebar di Kecamatan Juntinyuat, Kecamatan Pasekan dan Indramayu; (4) kepala daerah yang menjadi tempat penelitian. Hasil penelitian ini menghasilkan lima produk unggulan, yakni sirup pidada, dodol pidada, kecap mangrove, teh mangrove dan lulur mangrove. Kelima produk tersebut bersumber dari tiga spesies mangrove, yakni spesies Sonneratia caseolaris, pueraria phasealoides, Acanthus, Xylocarpus granatum.
\end{abstract}

Kata Kunci: Diversifikasi, mangrove, pangan alternative 


\section{PENDAHULUAN}

Kabupaten Indramayu terletak di pesisir utara Pulau Jawa, dengan panjang garis pantai sekitar 114,1 Km yang terdiri dari Panjang pantai berpasir sekitar 64,68 Km dan Panjang pantai berlumpur sekitar 44,91 Km. Sedangkan Luas Hutan Rakyat yang banyak ditumbuhi pohon bakau dan api-api,sekitar 15.553,28 Ha dengan sebaran Hutan Mangrove diluar kawasan hutan lindung seluas 4.370 Ha, Perkebunan Rakyat 8.808,71 Ha, PT. RNI 6.357,20 Ha (Bapeda Indramayu, 2015).

Potensi pesisir pantai di Indramayu yang banyak ditumbuhi pohon mangrove itu, merupakan aset berharga yang bisa dimanfaatkan untuk meningkatkan kesejahteraan masyarakat. Namun sayangnya kondisi pantai banyak yang rusak akibat terjangan abrasi, hal itu disebabkan hampir 18 ribu hektare hutan pantai di Indramayu kondisinya kritis. Salah satu penyebab utama kerusakan hutan mangrove di Indramayu karena kurang kesadarannya masyarakat tentang manfaat olahan dari mangrove sehingga bernilai ekonomi. Masyarakat berpendapat bahwa menjadikan hutan bakau sebagai area pertambakan lebih menguntungkan dari segi ekonomi ketimbang memanfaatkan mangrove menjadi olahan makanan, minuman atau menjadi bahan baku kosmetik.

Satu hal yang perlu digaris bawai bahwa pemanfaatan melalui hasil mangrove tidak akan berdampak pada habisnya spesies mangrove. Hal sebaliknya dengan diversifikasi produk olahan mangrove bisa meningkatkan kesejahteraan masyarakat pesisir Indramayu. Selain itu dengan memanfaatkan mangrove maka secara tidak langsung, akan dapat mengatasi ancaman rawan pangan bangsa Indonesia.

Tujuan dalam penelitian ini sebagai berikut; 1) merubah paradigma masyarakat pesisir kabupaten Indramayu bahwa tumbuhan mangrove dapat diversifikasi menjadi olahan makanan, minuman dan obat-obat yang bernilai ekonomi tinggi. 2) Meningkatkan kesejahteraan ekonomi masyarakat pesisir Indramayu.

\section{METODE PENELITIAN}

Area kajian meliputi 3 Kecamatan di yang terletak di pesisir Kabupaten Indramayu yang terbagi menjadi 3 desa yakni pabean udik, brondong dan Juntinyuat. Metode yang digunakan dalam penelitian adalah metode survey, yaitu metode yang dilakukan untuk mengadakan pemeriksaan yang berlangsung di lapangan atau lokasi penelitian. Data yang diperoleh dianalisis menggunakan analisis deskriptif kualitatif. Menurut I Made Wirartha (2006:155) metode analisis deskriptif kualitatif yaitu menganalisis, 
menggambarkan, dan meringkas berbagai kondisi, situasi dari berbagai data yang dikumpulkan berupa hasil wawacara atau pengamatan mengenai masalah yang diteliti yang terjadi di lapangan.

Mekanisme Kegiatan Penelitian ini bekerja sama dengan (1) dinas kelautan dan perikanan kabupaten Indramayu; (2) Persaudaran Perempuan Nelayan Indonesia (PPNI) kabupaten Indramayu; (3) Kelompok posdaya LPPM Universitas Wiralodra yang tersebar di Kecamatan Juntinyuat, Kecamatan Pasekan dan Indramayu; (4) kepala daerah yang menjadi tempat penelitian

\section{HASIL DAN PEMBAHASAN}

Berdasarkan hasil identifikasi dan survai awal mengenai jenis mangrove dan pemanfaatannya diperoleh 4 spesies mangrove di pesisir Indramayu yang dapat diolah menjadi produk olahan dari mangrove yaitu spesies Sonneratia caseolaris (Pidada), pueraria phasealoides (Kacang kerandang), Acanthus (Jeruju), Xylocarpus granatum (Nyirih). Selanjutnya setelah melakukan identifikasi sebaran mangrove maka dilakukkan pelatihan pembuatan mangrove yang terdiri dari:

\subsection{Pembuatan Dodol dan Sirop Buah Pidada}

Pembuatan dodol mangrove dilaksanakan di Desa Juntikebon Kecamatan Juntinyuat direncanakan akan melakukan olahan mangrove dirumah Ibu Rahmi. Baham yang di butuhkan untuk pembuatan sirop dan dodol mangrove yakni :1 kg kapidada, 1/4 gula pasir, 5 gram Vanily, 5 gram garam, 1 liter air. Sedangkan prosedur pembuatan secara umum yakni (1) cuci buah pidada dengan bersih; (2) Kupas buah pidada dari kulit buah; (3) Remas-remas buah pidada dan pisahkan dari bijinya; (4) Rebus buah pidada yang sudah dipisahkan dengan bijinya selama 30 menit; (5) masukkan bahan-bahan lainnya kedalam rebusan; (6) setelah matang endapkan selama 24 jam; (7) pisahkan antara air rebusan dengan endapannya; (8) air rebusan kemudian kemas menjadi sirop; (9) endapan dari rebusan campur bahan lain sehingga menjadi dodol buah pidada.

\subsection{Pembuatan Kecap Kacang Kerandang}

Tanaman kerandang (Canavalia virosa) tergolong kacang-kacangan, dapat dijumpai di Afrika, Amerika Selatan, Australia, India, dan Asia (Philiphina dan Indonesia). Tanaman ini tumbuh menjalar, menghasilkan polong dan biji. Keunggulan tanaman ini adalah mampu tumbuh pada lahan yang miskin unsur hara dan tahan terhadap kekeringan. Pada musim kemarau pun, tanaman ini tetap bertahan hidup di lahan pasir pantai. Biji kerandang memiliki 
nilai gizi yang setara dengan kedelai. Kandungan protein biji kerandang sebesar 37,30\%. biji kerandang dapat digunakan sebagai bahan substitusi kedelai. Biji kerandang juga mengandung asam amino termasuk asam amino esensial seperti lisin, fenila lanin, leusin dan isoleusin. Produk yang bisa dibuat diantaranya: (1) Kecap Kerandang; (2) Tempe kacang kerandang; (3) Susu kacang kerandang; (4) Tahu kacang kerandang.

Dalam penelitian ini produk yang dibuat yakni kecapa kacang kerandang. Bahan yang dibutuhkan yakni: Kacang kerandang, Garam krosok, Gula aren, Rempah-rempah. Sedangkan prosedur pembuatan kacang krandang yakni: (1) Kacang krandang direndam selama 4 hari, dan setiap hari airnya diganti; (2) Ditiriskan kemudian direbus selama 2 jam; (3) Mengupas kulit dan difermentasikan selama kurang lebih satu minggu; (4) Dijemur sampai kering antara 1 sampai 2 hari; (5) Dibacem dimasukan kedalam guci dengan diberi garam 1 kg kacang dan 2 kg garam; (6) Dibacem selama 10 - 11 hari; (7) Ditiriskan airnya diambil untuk dimasak dan ampas kacang untuk bahan baku pakan ternak atau pakan ikan; (8) Air baceman dimasak dan diberikan gula merah dengan perbandingan $1 \mathrm{~kg}$ kacang: $5 \mathrm{~kg}$ gula merah; (9) Untuk mendapatkan cita rasa kecap sesuai selera bisa dicampukan kaldu udang untuk kecap sari rasa udang dll; (10) Untuk membuat kuat rasa diberi rempah seperti kembang lawang; (11) Direbus sampai kecap matang; (12) Setelah matang disaring memakai saringan kain kasa, selanjutnya didinginkan dan dimasukan dalam kemasan.

\subsection{Pembuatan Teh Mangrove}

Tanaman jeruju dikenal juga dengan nama daruju, tanaman yang berasal dari tanah Melayu dan tanah Jawa tumbuh liar di daerah pantai, tepi sungai, serta tempat-tempat lain yang tanahnya berlumpur dan berair payau, tumbuh tegak atau berbaring pada pangkalnya; tinggi 0,5-2 meter, berumpun banyak. Tumbuhan daruju mempunyai daun tunggal, bertangkai pendek, letak berhadapan bersilang. Helaian daun berbentuk memanjang atau lanset, pangkal dan ujung runcing, tepi bercangap menyirip dengan ujung-ujungnya berduri tempel, panjang 9-30 cm, lebar 4-12 cm. Daun pelindung berlapis dua, bagian dalam lebih kecil, gugur sebelum bunga mekar, kelopak panjang 12,5-15 mm, berbagi empat, mahkota panjang 3-4,5 cm, bertabung putih, bibir bulat telur, ujung bertaju tiga, ungu kebiruan. Daun, akar dan biji mengandung saponin, flavonoida dan polifenot, di samping itu bijinya juga mengandung alkaloida. Daruju memiliki khasiat obat, terutama pada akar yang mengandung flavone dan asam amino.

Tumbuhan daruju diyakini berkhasiat sebagai antiradang (antiflogistik) dan peluruh dahak (ekspektorans). Biji berkhasiat sebagai pembersih darah. Akar digunakan untuk 
pengobatan : radang hati (hepatitis) akut dan kronis, pembesaran hati dan limpa, pembesaran kelenjar limpa, termasuk pembesaran kelenjar limpa pada tuberkulosis (TBC) kulit, gondongan, sesak napas, cacingan, nyeri lambung, sakit perut, kanker, terutama kanker hati.

Dalam pembuatan teh ini diikuti dari berbagai elemen masyarakat. Penelitian pembuatan teh mangrove melibatkan masyarkat, mahasiswa/i, petani mangrove, ibu-ibu PKK dan dosen. Pembuatan teh dari daun pucuk jeruju ini dilaksanakan 1 hari, pada tanggal 18 April 2016.

Dalam pembuatan alat yang dibutuhkan seperti bakul bambu, tampi, gunting, dll. Sedangkan Alat disediakan untuk mempermudah pembuatan. Selain itu bahan yang dibutuhkan daun pucuk jeruju sebagai bahan utama. Prosedur yang dibutuhkan dalam pembuatan yakni (1) Memetik pucuk daun jeruju, dilakukan sebaiknya pagi hari sebelum matahari terbit supaya menghasilkan teh yang berkualitas; (2) Mendiamkan daun jeruju selama kurang lebih 2 jam, lalu dicincang sesuai dengan selera (kecil/besar); (3) Daun jeruju yang sudah dicincang dijemur pada pagi hari sampai siang hari; (4) Ditiriskan; (5) Untuk produk teh celup digiling dengan mesin penggiling kopi, bisa juga langsung dikonsumsi tanpa digiling.

\subsection{Pembuatan Lulur Mangrove}

Pohon dari buah nyirih berukuran sedang, tinggi mencapai $22 \mathrm{~m}$, dan bergaris tengah hingga $1 \mathrm{~m}$, terkadang dijumpai pohon berakar banir, sering dijumpai sistem akar berupa akar napas atau permukaan akar seperti pita. Kulit batang bercelah atau bersisik. Daun majemuk menyirip genap, berseling, bentuk anak daun jorong atau bulat telur sungsang. Bunga malai tumbuh pada ketiak daun, uniseksual, daun-daun mahkota berwarna putihkrem. Buah kapsul, halus berkayu, bergaris tengah hingga $25 \mathrm{~cm}$, mengandung $6-18$ biji. Biji berbentuk persegi empat, panjang hingga $6 \mathrm{~cm}$, berwarna coklat. Sedangkan manfaatnya dapat sebagai bedak dingin, obat dan lulur yang sehat untuk kulit.

Pelatihan pembuatan lulur dari daun nyirih (Xilocarpus) ini dilaksanakan 1 hari, pada tanggal 7 Mei 2016. Dalam pembuatan alat yang dibutuhkan seperti pisau, tampi, saringan, alat penumbuk/gilingan kopi, mangkuk, dll. Sedangkan alat disediakan untuk mempermudah pembuatan yakni bahan yang dibutuhkan daun nyirih sebagai bahan utama. Selanjutnya prosedur pembuatan yakni (1) Pengambilan daun nyirih (Xilocarpus $s p$ ) secukupnya; (2) ditiriskan supaya getahnya turun; (3) Dikupas, diiris yang tipis lalu dijemur sampai kering; (4) Dilembutkan dengan menggunkan mesin penggiling kopi; (5) Setelah lembut disaring sampai mendapatkan butiran yang sangat halus. 

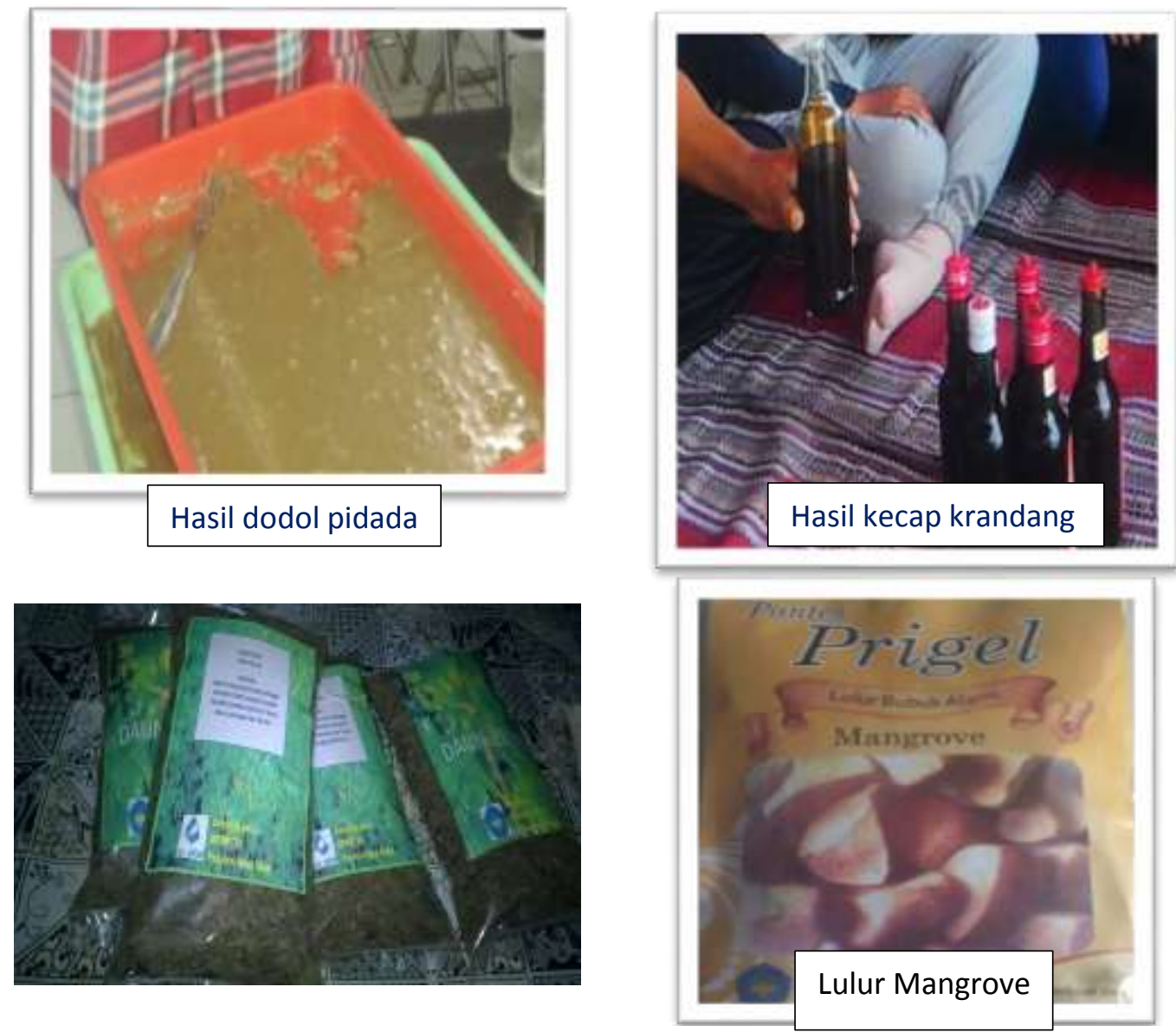

\section{Gambar 4.1 Hasil diversifikasi olahan mangrove}

\section{KESIMPULAN}

Pesisir Pantai Indramayu yang banyak ditumbuhi pohon mangrove ini menghasilkan lima produk unggulan, yakni sirup pidada, dodol pidada, kecap mangrove, teh mangrove dan lulur mangrove.

Kelima produk tersebut bersumber dari tiga spesies mangrove, yakni spesies Sonneratia caseolaris, pueraria phasealoides, Acanthus, Xylocarpus granatum.

\section{DAFTAR PUSTAKA}

Bengen, D. G. 2000. Pengenalan dan Pengelolaan Ekosistem Mangrove. Bogor: PKSPLIPB.

Hidayat, T. 2014. Pengembangan Beras Analog Berbasis Buah Lindur, Sagu, dan Kitosan Dalam Mendukung Ketahanan Pangan Nasional Berkelanjutan. Bogor: Departemen Teknologi Hasil Perairan Institut Pertanian Bogor 
Nikijuluw Victor. 2001. Populasi dan Sosial Ekonomi Masyarakat Pesisir serta Strategi Pemberdayaan Mereka Dalam Konteks Pengelolaan Sumberdaya Pesisir Secara Terpadu. Bogor: IPB Bogor.

Riduwan. 2009. Belajar Mudah Penelitian. Bandung: Alfabeta.

Saparinto, C. 2007. Pendayagunaan ekosistem mangrove mengatasi kerusakan wilayah pantai dan meminimalisasi dampak gelombang tsunami. Semarang: Effhar dan Dahara Prize.

Wirartha, I. M. 2006. Metode Penelitian Sosial Ekonomi. Yogyakarta: Andi Offset. 